\title{
Physico-mechanical properties of topical formulations based on different polymers
}

\author{
Propriedades físico mecânicas de formulações tópicas à base de diferentes polímeros
}

\author{
Victor Hugo Pacagnelli Infante, Lívia Salomão Calixto, Patrícia M. B. G. Maia Campos \\ School of Pharmaceutical Sciences of Ribeirão PretoUniversity of São Paulo - Ribeirão Preto - Brazil \\ Email: pmcampos@usp.br
}

\begin{abstract}
The texture properties of formulations can be related to their sensory properties, and the correct choice of raw materials is an important tool to improve the sensorial properties of cosmetic formulations. This way, the objective of this study was to evaluate the physical-mechanical properties of different polymers applied in the cosmetic formulations and analyze how their concentration can affect these parameters. Twelve gel formulations were developed with four different polymers often used in cosmetic formulations in different concentrations: Ammonium Acryloyldimethyltaurate/VP Copolymer, Hydroxyethylcellulose, Polyacrylamide (and) C13-14 Isoparaffin (and) Laureth-7, and Acrylates/C10-30 Alkyl Acrylate Crosspolymer. The system of physical-mechanical properties analysis was applied to characterize the texture profile in different parameters, as the cohesiveness and viscosity. The analysis of the obtained data showed that higher concentration of acrylate polymer is necessary to obtain a significant influence in the physical-mechanical parameters of the formulation. The parameter most affected by the hydroxylethylcellulose was the work of shear. The blend of Polyacrylamide (and) C13-14 Isoparaffin (and) Laureth-7 showed the most pronounced alterations in the texture profile. Ammonium Acryloyldimethyltaurate/VP Copolymer did not alter the physico-mechanical properties of the formulations studied and Acrylates/C10-30 Alkyl Acrylate Crosspolymer altered the texture parameters only when used in the lowest and the highest concentrations in the formulations. Finally, the type of polymers could result in formulations with different physicomechanical properties, reflecting its performance when applied on the skin.
\end{abstract}

Keywords: texture profile, cosmetic formulations, polymers

\begin{abstract}
Resumo
As propriedades de textura das formulações estão relacionadas com as propriedades sensoriais e a escolha correta das matérias-primas é uma importante ferramenta para melhorar as propriedades sensoriais das formulações cosméticas. Dessa forma, o objetivo deste estudo foi avaliar as propriedades físico-mecânicas de diferentes polímeros utilizados em formulações cosméticas e analisar como a concentração dos mesmos pode afetar estes parâmetros. Doze formulações de gel foram desenvolvidas com quatro diferentes polímeros altamente utilizados em formulações cosméticas em diferentes concentrações: Acryloydimethyltaurate de Amônio/Copolímero VP, Hidroxietilcelulose, Poliacrilamida (e) Isoparafina C13-14 (e) Laureth-7 e Acrilatos/Acrilato de Alquil C10-30Crossopolímero. O sistema de análise das propriedades físicomecânicas foi utilizado para caracterizar o perfil de textura em diferentes parâmetros, como coesividade e viscosidade. A análise dos dados obtidos mostrou que é necessária uma maior concentração de polímero de acrilato para obter uma influência significativa nos parâmetros físico-mecânicos da formulação. O parâmetro de textura mais afetado pela hidroxietilcelulose foi o trabalho de cisalhamento. O blend de Polyacrylamide (and) C13-14 Isoparaffin (and) Laureth-7 mostrou alterações mais pronunciados nos perfis de textura. Ammonium Acryloyldimethyltaurate/VP Copolymer não alterou as propriedades físico mecânicas das formulações e o polímero Acrylates/C10-30 Alquil Acrilate Crosspolymer alterou essas propriedades somente quando foi usado nas menores e maiores concentrações. Por fim, o tipo de polímero pode resultar em formulações com diferentes propriedades físico mecânicas, o que reflete na performance das mesmas quando aplicadas na pele.
\end{abstract}

Palavras-chave: perfil de textura, formulações cosméticas, polímeros 


\section{Introduction}

Sensory analysis is very important during the development of cosmetic formulations. Formulations with good sensory properties can represent a better reception by the consumer and, consequently, adherence to treatment. Quantitative Descriptive Analysis $\left(\mathrm{QDA}^{\circledR}\right)$ and the Spectrum ${ }^{\mathrm{TM}}$ Descriptive Analysis (SDA) are two methods to evaluate the sensorial properties of topical products, however, these methods require time and a trained panel. $(1,2)$ For this, instrumental measurements can be chose as an alternative, but it is necessary to study which methods are effective and useful for the proposed analysis. Such analyses can help the pharmaceutical and cosmetics companies to save time and money. $(3,4)$

During the development of topical formulations, information about how the raw material(s) can influence the final product is very important. Many parameters can be modified, such as concentration of ingredients, protocol, and combination of raw materials. Such modifications can improve the physical characteristics of the formulation, which could reflect on the sensory proprieties. $(5,6)$

This way, the correct choice of raw materials is essential to obtain an exceptional topical formulation, but more than quality, it is necessary to have information about how it can improve the physical-mechanical quality of the topical formulation. $(7,8)$ Different types of polymers are used to create gel formulations or to improve the rheological characteristics on other cosmetic formulations, such as emulsions. (9) In this context, knowledge about how they can influence the physicalmechanical characteristics is a good way to solve challenges in pharmaceutical and cosmetic technology. (10) The objective of this work was to study the physicalmechanical properties of different polymers applied in the topical formulations and to analyze how the polymer concentration can affect these properties using a system of physical and mechanical properties analysis.

\section{Material and Methods}

\section{Developed formulations}

Twelve gel formulations with four polymers in different concentrations were developed (Table I). The polymer concentrations were selected by the minimum, medium and maximum values of concentration use provided by the data sheets. Hydroxyethylcellulose (HEC, Natrosol $^{\circledR}$ - Ashland) and the Polyacrylamide (and) C13-14 Isoparaffin (and) Laureth-7 mixture (SEPIGEL 305 ${ }^{\mathrm{TM}}$

\section{Introdução}

Para desenvolver uma formulação tópica, é necessário obter uma fórmula estável e com um sensorial agradável. Uma formulação com alto desempenho sensorial significa uma boa recepção pelo público, aderência ao tratamento e demanda pelo produto. A Análise Descritiva Quantitativa e a Análise Descritiva do Spectrum TM (SDA) são dois métodos para avaliar as propriedades sensoriais de produtos tópicos. No entanto, esses métodos exigem tempo e um painel treinado. $(1,2)$ Para isso, as medidas instrumentais podem ser escolhidas como uma alternativa, mas é necessário estudar quais métodos são eficazes e úteis para a análise proposta. Isso representa uma melhoria na indústria farmacêutica, pois poderia ajudar a economizar tempo e dinheiro. $(3,4)$ Durante o desenvolvimento de formulações tópicas, informações sobre como a matéria-prima pode influenciar o produto final são muito importantes. Muitos parâmetros podem ser modificados como concentração de ingredientes, protocolo e combinação de matérias-primas. Pode melhorar as características físicas da formulação, o que poderia refletir nas propriedades sensoriais. $(5,6)$

Desta forma, a escolha correta das matérias-primas é essencial para obter uma formulação tópica excepcional, mas mais do que qualidade, é necessário obter informações sobre como melhorá-la. $(7,8)$ Diferentes tipos de polímeros são usados para criar formulações em gel ou para melhorar as características reológicas em outras formulações cosméticas. (9) Neste contexto, o conhecimento sobre como eles podem influenciar as características físico-mecânicas é uma boa maneira de resolver dificuldades na tecnologia farmacêutica e cosmética. (10)

O objetivo deste trabalho foi estudar as propriedades físico-mecânicas de diferentes polímeros utilizados na indústria farmacêutica e analisar como a concentração pode afetar esses parâmetros por meio de um sistema de análise de propriedades físicas e mecânicas.

\section{Material e Métodos}

\section{Desenvolvimento de formulações}

Foram desenvolvidas doze formulações de gel com quatro polímeros em diferentes concentrações para analisar os efeitos dos mesmos nas propriedades de textura (Tabela I). As concentrações dos polímeros foram selecionadas pelos valores mínimo, médio e máximo de concentração fornecidos pelas fichas técnicas. Para 
- SEPPIC) were applied in the minimum concentration of $2 \%$ based on the sensitivity of the Texture Analysis system to perform the physical-mechanical analysis.

All formulations were developed considering a minimal variation on their components to avoid interferences in the physical-mechanical properties results. To confirm their stability, an aliquot of 5 grams of each formulation was weighed and centrifuged at $3000 \mathrm{rpm}, 3$ cycles of 30 minutes each (CentriBio) at room temperature.

The polymers used in the gel formulations were Ammonium Acryloyldimethyltaurate/VP Copolymer (Aristoflex $\mathrm{AVL}^{\circledR}$ - Clariant) and HEC. Each was weighed and prepared in a volume of water sufficient to obtain 100 $\mathrm{g}$ of formulation. Preservatives (ChemyUnion) were weighed and dissolved in the required amount of propylene glycol (Synth) and incorporated in the formulation. For HEC, the polymer solution was heated to 60 ${ }^{\circ} \mathrm{C}$ in a hot plate (Fisaton) and stirred until the polymer chain was constructed. o Poliacrilamida (e) Isoparafina C13-14 (e) Laureth-7 (SEPIGEL 305 ${ }^{\mathrm{TM}}$ - SEPPIC) e o hydroxyethylcellulose (HEC, Natrosol ${ }^{\mathrm{TM}}$ - Ashland) utilizou-se o mínimo de $2 \%$ devido à sensibilidade do sistema de Análise de Textura para realizar as análises físico-mecânicas.

Todas as formulações foram desenvolvidas considerando uma variação mínima em seus componentes para evitar interferências nos resultados das propriedades físico-mecânicas. Para confirmar a sua estabilidade, $5 \mathrm{~g}$ de cada formulação foi centrifugadas a $3000 \mathrm{rpm}, 3$ ciclos de 30 minutos (CentriBio) à temperatura ambiente. Acryloydimethyltaurate de Amônio / Copolímero VP (Aristoflex AVL - Clariant) e HEC foram pesados e dispersos em quantidade suficiente de água para obter $100 \mathrm{~g}$ de formulação. Os conservantes foram pesados e solubilizados na quantidade requerida de propilenoglicol (Synth) e incorporados na formulação. Para HEC, a solução com o polímero foi aquecida até $60^{\circ} \mathrm{C}$ em

Table 1/ Tabela 1 - Formulation composition / Composição das Formulações

\begin{tabular}{|c|c|c|c|c|}
\hline Polymer / Polímero & INCI Name / INCI Nome & Conc. 1 & Conc. 2 & Conc. 3 \\
\hline Aristoflex ${ }^{\circ}$ AVC & $\begin{array}{l}\text { Ammonium Acryloyldimethyltaurate/VP Copolymer } \\
\text { Acryloydimethyltaurate de Amônio/Copolímero VP }\end{array}$ & $0.5 \%$ & $2.5 \%$ & $5.0 \%$ \\
\hline Natrosol ${ }^{\mathrm{TM}} 250 \mathrm{HR} / \mathrm{HHR}$ & $\begin{array}{l}\text { Hydroxyethylcellulose } \\
\text { Hidroxietilcelulose }\end{array}$ & $2.0 \%$ & $3.0 \%$ & $5.0 \%$ \\
\hline SEPIGEL'TM 305 & $\begin{array}{l}\text { Polyacrylamide (and) C13-14 Isoparaffin (and) Laureth-7 } \\
\text { Poliacrilamida (e) Isoparafina C13-14 (e) Laureth-7 }\end{array}$ & $2.0 \%$ & $3.0 \%$ & $5.0 \%$ \\
\hline CARBOPOL $^{\circ}$ ULTREZ 20 & $\begin{array}{c}\text { Acrylates/C10-30 Alkyl Acrylate Crosspolymer } \\
\text { Acrilatos/Acrilato de Alquil C10-30 Crossopolímero }\end{array}$ & $1.0 \%$ & $4.0 \%$ & $8.0 \%$ \\
\hline
\end{tabular}

Polyacrylamide (and) C13-14 Isoparaffin (and) Laureth-7 and Acrylates/C10-30 Alkyl Acrylate Crosspolymer (AAAC, Carbopol - Lubrizol) were weighed and dissolved in a volume of water sufficient to obtain 100 $\mathrm{g}$ of formulation. Preservatives (ChemyUnion) and EDTA (LabChem) were weighed and dissolved in the required amount of propylene glycol and incorporated into the formulation. The $\mathrm{pH}$ was then adjusted to 6.0 using AMP 95 (ANGUS Chemical) to have the formation of polymeric netting. All the formulations utilized $3 \%$ of propylene glycol (Synth) and sufficient concentration of preservative $(0.8 \%)$. placa quente (Fisaton) e foi agitada até a construção da cadeia polimérica.

Poliacrilamida (e) Isoparafina C13-14 (e) Laureth-7 foram dispersos em quantidade suficiente de água para obter $100 \mathrm{~g}$ de formulação. Os conservantes e EDTA (LabChem) foram solubilizados na quantidade requerida de propilenoglicol e incorporados na formulação. Acrilatos / C10-30 Acrilato Alquil Crosspolymer (AAAC, Carbopol - Lubrizol) foram pesados e dispersos em quantidade suficiente de água para obter 100 $\mathrm{g}$ de formulação. Os conservantes (ChemyUnion) e EDTA (LabChem) foram solubilizados na quantidade necessária de propilenoglicol e incorporados à formulação e depois disso, o pH foi ajustado para 6,0 usando AMP 95 (ANGUS Chemical) para se obter a formação do polímero.

Todas as formulações utilizaram $3 \%$ de propilenogli- 


\section{Texture Analysis}

For the texture analysis, the system of physical and mechanical properties analysis, a model TA.XT/Plus 50 instrument (Stable Microsystems, United Kingdom), was utilized. The method used to determine the texture consisted of inserting a probe in the analytical sample, two consecutive times, with a defined speed and depth, leading to pre-defined recovery period between the end of the first compression and the beginning of the second one. From the resulting graph of force $(\mathrm{N})$ per time (t) the following parameters were obtained: cohesiveness, consistency, firmness, viscosity index and work of shear. For work of shear the height was $25 \mathrm{~cm}$ and the probe velocity $30 \mathrm{~mm} / \mathrm{s}$. The texture analyses were established with $100 \mathrm{~mm}$ of height and $30 \mathrm{~mm} / \mathrm{s}$ of velocity. col (Synth) e a concentração suficiente de conservante $(0,8 \%)$.

\section{Análise De Textura}

Para a análise de textura, utilizou-se o sistema de análise de propriedades físicas e mecânicas, modelo TA.XT / Plus 50 (Stable Microsystems, Reino Unido). O método usado para determinar a textura consiste em inserir uma sonda na amostra analítica, duas vezes seguidas, com velocidade e profundidade definidas, levando a um período de recuperação pré-definido entre o final da primeira compressão e o início da segunda. A partir do gráfico de força resultante $(\mathrm{N})$ por tempo $(\mathrm{t})$, foram obtidos os seguintes parâmetros: coesão, consistência, firmeza, índice de viscosidade e trabalho de cisalhamento (Figura 1). Para o trabalho de cisalhamento a altura foi

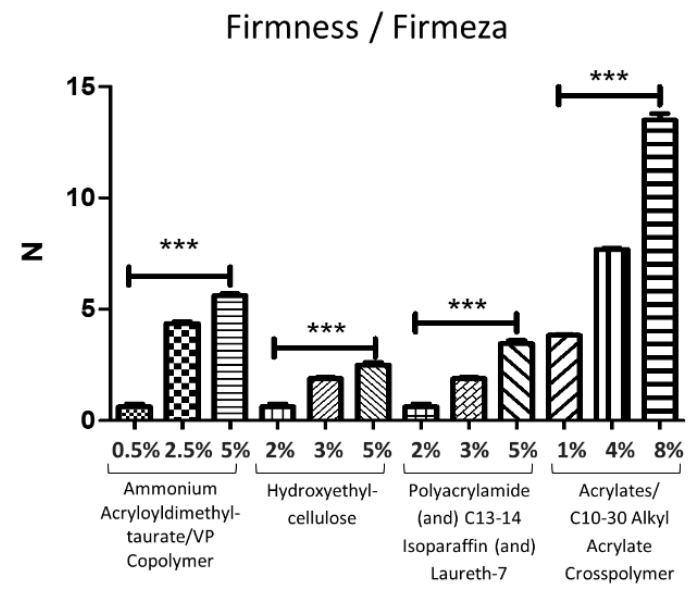

Work of shear / Trabalho de cisalhamento

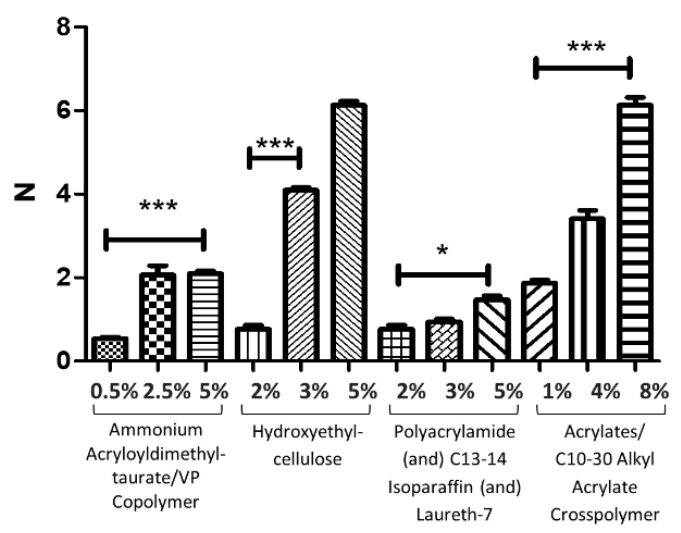

Cohesiveness / Coesividade

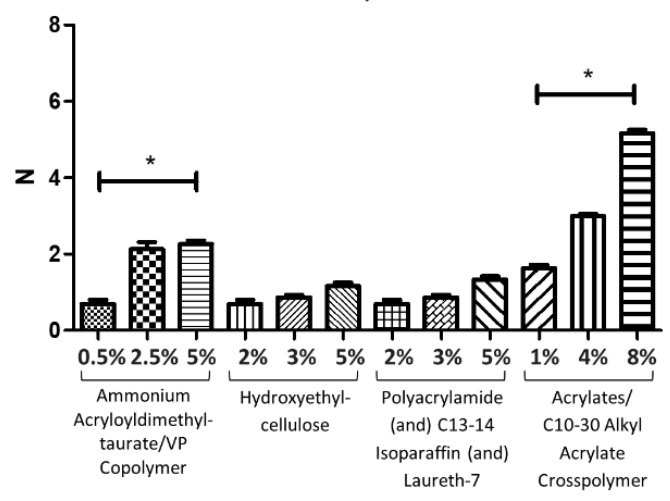

Figure 1/ Figura 1 - Influence of polymer concentration on cohesiveness, firmness and work of shear, where $(*)$ means $0.01<\mathrm{p}<0.05$; $(* *)$ means $0.001<\mathrm{p}<0.01$, and $(* * *)$ means $\mathrm{p}<0.001$. / Influência da concentração de polímeros na coesão, firmeza e trabalho de cisalhamento, onde $\left(^{*}\right)$ significa $0.01<\mathrm{p}<0.05$; (**) $0.001<\mathrm{p}<0.01$ e $(* * *) \mathrm{p}<0.001$. 


\section{Statistical Analysis}

The data obtained was compared by Kruskal and Wallis and a Dunns posttest $(\alpha=0.05)$, except when the data had a normal distribution, in the cases of consistency [Polyacrylamide (and) C13-14 Isoparaffin (and) Laureth-7], work of shear [HEC and Polyacrylamide (and) C13-14 Isoparaffin (and) Laureth-7], and viscosity [Polyacrylamide (and) C13-14 Isoparaffin (and) Laureth-7]. In latter cases, the one-way analysis of variance test was used and the Tukey posttest to compare the concentrations.

\section{Results and Discussion}

The Ammonium Acryloyldimethyltaurate/VP Copolymer is characterized as an anionic gel, easy to work with because is pre-neutralized and stable. It can also be used as a thickening agent in topical and cosmetic formulations, such as emulsions. The concentrations of $0.5 \%$ and $5.0 \%$ showed high significant difference for all parameters, but cohesiveness presented the lower statistical difference- Thus, this polymer needs a greater concentration change to present a significant contribution on the physical-mechanical parameters analyzed. The Polyacrylamide (and) C13-14 Isoparaffin (and) Laureth-7 is pre-neutralized and forms inverse emulsion instantly by simply adding water. With this formulation we observed a linear result with the increase of its concentration on the physical mechanical proprieties. This could be more related with the inverse emulsion characteristic, since its composition can form globules, not only polymeric networks. (11)

For AAAC, it was observed that to obtain significant changes on physical and mechanical characteristics it was necessary to use eight times more of this polymer. Cohesiveness, firmness, and work of shear are properties with similarities as they are closely related to the polymer structure of the selected material. It is important to highlight the influence of cohesiveness and work of shear on the performance of the formulation on the skin. Thus, they can impact the sensorial properties of the formulations. (12). This way, polymers with higher differences between the concentrations can have the most influence on sensorial characteristics and acceptance of topical formulation. This can be observed in the AAAC, for example, with a good correlation between these three parameters.

It is interesting to highlight the impact of the type of the polymers, not just the variation on concentration, in the work of shear. This result can be observed especially de $25 \mathrm{~cm}$ e a velocidade de $30 \mathrm{~mm} / \mathrm{s}$. As análises de textura foram estabelecidas com $100 \mathrm{~mm}$ de altura e 30 $\mathrm{mm} / \mathrm{s}$ de velocidade.

\section{Análise Estatistica}

De acordo com a distribuição amostral dos dados obtidos, os mesmos foram analisados pelo teste não paramétrico de Kruskal e Wallis e Dunn $(\alpha=0,05)$ e pelo teste paramétrico one-way de análise de variância e o teste complementar de Tukey para comparar as concentrações quando os dados que apresentaram distribuição normal para os dados dos parâmetros de consistência [Poliacrilamida (e) Isoparafina C13-14 (e) Laureth-7], trabalho de cisalhamento [HEC e Poliacrilamida (e) Isoparafina C13-14 (e) Laureth-7] e viscosidade [Poliacrilamida (e) Isoparafina C13-14 (e) Laureth-7].

\section{Resultados e Discussão}

O polímero Amônio Acryloydimetethyltaurate/VP Copolymer é caracterizado como um gel aniônico, sendo de fácil preparação por ser pré-neutralizado e estável. Também pode ser utilizado como agente espessante em formulações cosméticas, como as emulsões. As concentrações de $0,5 \%$ e 5,0\% apresentaram diferença significativa para todos os parâmetros, porém, o parâmetro a coesividade apresentou a menor diferença estatística. Dessa forma, foi possível observar que este polímero necessita de maior variação em sua concentração para influenciar significativamente os parâmetros físico-mecânicos analisados.

Poliacrilamida (e) C13-14 isoparafina (e) Laureth-7 é pré-neutralizada e forma uma emulsão inversa instantaneamente simplesmente adicionando água. Nesta formulação, observamos um resultado linear com o aumento de sua concentração nas propriedades físico-mecânicas. Poderia estar mais relacionado com a característica de emulsão inversa, já que em sua composição é possível observar a formação de glóbulos e não apenas redes poliméricas. (11) Para o polímero AAAC observou-se que, para obter mudanças significativas nas características físico-mecânicas, foi necessário utilizar oito vezes mais desse polímero.

Coesão, firmeza e trabalho de cisalhamento são propriedades com similaridades, pois estão intimamente relacionadas à estrutura do polímero do material selecionado. É importante destacar a influência da coesão e do trabalho de cisalhamento no desempenho da formulação sobre a pele. Assim, podem impactar nas propriedades sensoriais das formulações.(12) Desta forma, polímeros com maiores diferenças entre as concentra- 
between the formulations with high polymer concentration. Likely this characteristic is highly correlated with the firmness. Both the work of shear and firmness presented significant difference not just between the different concentrations, but also the type of polymer.

The increase in polymer concentration results in an increase in the physical and mechanical parameters of formulations. However, in the formulations based on HEC, the firmness parameter was the most influenced by the polymer concentration, differently than in the other formulations. For the others, the work of shear was the most affected, showing a more direct influence with the sensorial. $(12,13)$ Firmness is a feature related to the structure of the formula itself, so increases in HEC concentrations will mainly influence how the polymeric formula behaves when stored, for example (Figure 1).

Viscosity and consistency are properties related with the structure of the formulation. (14) This way, increases on concentration of certain polymers as HEC, for example, can result more structured formulations. This information is important for the stability of the final formulation. Both viscosity and consistency increase linearly with the increase of polymer concentration. Thus, the physico-mechanical characteristics end

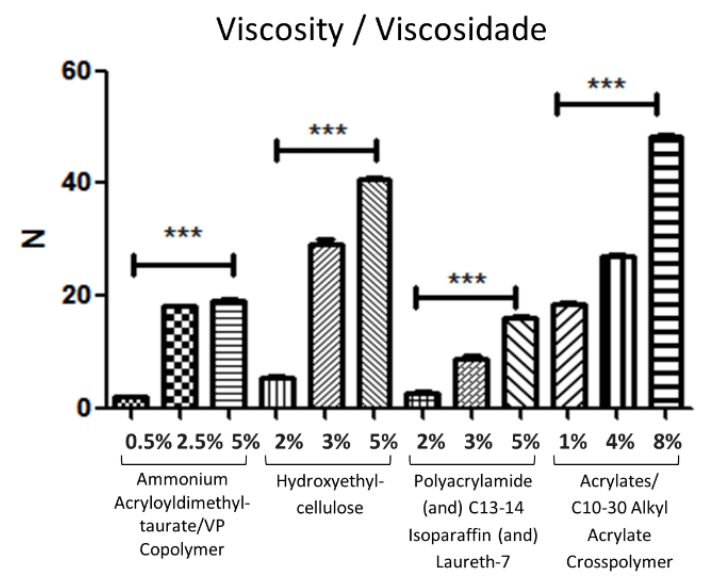

ções podem influenciar mais em sensorial e aceitação de formulação tópica. Esse comportamento pode ser observado no AAAC, por exemplo, com uma boa correlação entre estes três parâmetros.

É interessante destacar o impacto do tipo de polímero, e não apenas a variação da concentração, no trabalho de cisalhamento. Este resultado pode ser observado especialmente entre as formulações com alta concentração de polímeros. Provavelmente esta característica está muito correlacionada com a firmeza. Ambos, trabalho de cisalhamento e firmeza, apresentaram diferença significante não apenas entre as diferentes concentrações, mas o tipo de polímero também.

$\mathrm{O}$ aumento da concentração do polímero resulta num aumento das propriedades físicas e mecânicas. No entanto, para a formulação a base de HEC, o parâmetro firmeza foi a mais influenciada pela concentração do polímero, diferentemente das demais formulações. Para os demais, o trabalho de cisalhamento foi o mais afetado, mostrando uma influência mais direta com o sensorial. $(12,13)$ Firmeza é uma característica relacionada à estrutura da própria formulação, portanto, os aumentos nas concentrações de HEC influenciarão principalmente como a fórmula polimérica se comporta quando armazenada, por exemplo (Figura 1).

Viscosidade e consistência são propriedades relacionadas com a estrutura da própria formulação. (14) Desta forma, o aumento da concentração de certos polímeros como o HEC, por exemplo, podem resultar em formulações mais estruturadas. Esta informação é importante para a estabilidade da formulação final. Tanto a viscosidade como a consistência aumentam linearmente com

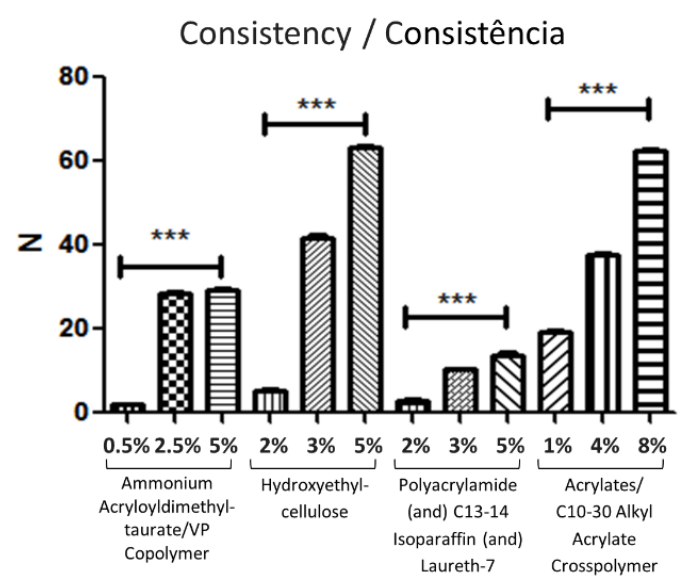

Figure 2/ Figura 2 - Influence of polymer concentration on viscosity and consistency, where $(* * *)$ means $\mathrm{p}<0.001$. / Influência da concentração de polímero na viscosidade e consistência, onde $(* * *)$ significa $\mathrm{p}<0.001$ 
up behaving in the same way with the increase of the concentrations of the studied polymers (Figure 2).

The structure of polymeric material has an important role on these characteristics. Polymers with a cyclic lateral chain, AAAC, had less improvement of viscosity and consistency with the increase of polymer concentration. This polymer has a cyclic amide on its lateral chain, which means that the total volume of polymer will be more representative and can change the structural properties of formulations as viscosity. The carbomer AAAC was different because its lateral chain does not have a cyclic chain, so it was possible to create a better cross-linked 3D-structure, with a more compact formulation, with a large increase on physical-mechanical parameters with lower concentrations of polymer. (15-17)

HEC has a smaller lateral chain when compared to the other polymers cited previously. For this reason, when the concentration is increased 2.5 times, the results of viscosity and consistency are the same as for the AAAC when it was increased 8 times. (18-21)

It was possible to observe statistical differences between all the formulations with the higher polymer concentrations. However, in the lower concentrations significant differences between the formulations with different polymers were not found. Thus, regarding consistency, a significant difference $(p<0.05)$ was found between the minimum values of HEC, AAAC, and Polyacrylamide (and) C13-14 Isoparaffin (and) Laureth-7, likely because Polyacrylamide (and) C13-14 Isoparaffin (and) Laureth-7 is an inverse emulsion. In Figure 2, it is possible to observe that increases in concentration of Polyacrylamide (and) C13-14 Isoparaffin (and) Laureth-7 did not greatly influence consistency.

Jones, Woolfson, and Brown (1997) (22) demonstrated in their study that cohesiveness decreased with the increase of the polymers' concentration. In our study, this property had a non-significant increase to HEC and Polyacrylamide (and) C13-14 Isoparaffin (and) Laureth-7, however, for Ammonium Acryloyldimethyltaurate/ VP Copolymer and AAAC it was possible to observe a significative increase $(p<0.05)$ with the increase of polymer concentration. Additionally, the higher concentration of AAAC was significant different than the other polymers $(\mathrm{p}<0.001)$ in the higher concentrations. It is important to highlight that in their study, HEC was combined with chlorhexidine, which could modify this parameter.

Calixto and Maia Campos (2017) (12) showed in their study that the relationship between firmness and cohesiveness was perfect and positive, that is, if one of these parameters increases the other will also increase proportionally. In our study it happens with all formula- o aumento da concentração dos polímeros. Assim, as características físico-mecânicas acabam se comportando da mesma forma com o aumento das concentrações dos polímeros estudados (Figura 2).

A estrutura do material polimérico tem um papel importante nessas características. Polímeros com cadeia lateral cíclica, Acryloydimethyltaurate de Amônio/ Copolímero VP, tiveram menor melhora da viscosidade e consistência com o aumento da concentração de polímero. Este polímero tem uma amida cíclica na sua cadeia lateral, o que significa que o volume total de polímero será mais representativo e pode alterar as propriedades estruturais das formulações como viscosidade. Para o carbômero AAAC foi diferente porque sua cadeia lateral não possui uma cadeia cíclica, sendo possível estruturar uma melhor estrutura $3 \mathrm{D}$ reticulada, tendo uma formulação mais compacta, com grande aumento nos parâmetros físico-mecânicos com menor concentração de polímero. (15-17)

A HEC possui uma cadeia lateral menor quando comparada aos demais polímeros citados anteriormente. Por essa razão, quando a concentração aumenta 2,5 vezes, os resultados de viscosidade e consistência são semelhantes ao aumento de 8 vezes na concetração do acrilato Acrilates/C10-30 Alquil Acrilate. (18-21)

Foi possível observar diferenças estatística entre todas as formulações com as maiores concentrações de polímeros. No entanto, nas concentrações mais baixas não foram encontradas diferenças significativas entre as formulações com diferentes polímeros. Entretanto, para a consistência, foi encontrada uma diferença significativa $(p<0,05)$ entre os valores mínimos de HEC, AAAC, e Poliacrilamida (e) Isoparafina C13-14 (e) Laureth-7, provavelmente porque o Poliacrilamida (e) Isoparafina C13-14 (e) Laureth-7 é uma emulsão inversa. Na Figura 2 é possível observar que aumentos na concentração de Poliacrilamida (e) Isoparafina C13-14 (e) Laureth-7 não influenciaram de forma pronunciada na consistência.

Jones, Woolfson, e Brown (1997) (22) mostraram em seu estudo que a coesão diminuiu com o aumento da concentração de polímeros como HEC. Em nosso estudo, essa propriedade teve um aumento não significativo para HEC e Poliacrilamida (e) Isoparafina C13-14 (e) Laureth-7, no entanto, para Acryloydimethyltaurate de Amônio / Copolímero VP e AAAC foi possível observar um aumento significativo $(\mathrm{p}<0,05)$ com o aumento da concentração de polímero. Além disso, a maior concentração de HEC foi significativamente diferente dos demais polímeros $(p<0,001)$ nas maiores concentrações. É importante ressaltar que, no estudo citado, o HEC foi combinado com a clorexidina, o que poderia modificar esse parâmetro. 
tions as the concentration of polymers increases. However, for HEC the difference between both parameters was higher in relation to the others. This may affect the sensory properties of the formulation, since cohesiveness is related to the performance of the formulation when applied, while the firmness is more correlated with the structure of the formulation. In fact, it was possible to observe the very similar behavior between work of shear and cohesiveness in the measurements (Figure 2). However, for HEC, the alterations in the concentration reflected in a higher increase in the firmness, likely because the HEC did not present lateral chains in its structure.

Higher viscosities associated to carbomers compared to other synthetic polymers were found in the literature. $(23,24)$ Even with this superior behavior, all the viscosities in minimal concentrations showed no significant difference between each other and low values. This characteristic is desired in cosmetic vehicles because of their high viscosity values, which implies a superior work of shear on skin, impairing the spreadability. (25, 26)

All polymers, with their structural characteristics, can help to improve sensorial proprieties; however, the knowledge about how polymers and their concentrations can influence the sensorial proprieties is important for the correct choice of these raw materials. (5)

Finally, considering that there are a few studies reported to physico-mechanical properties of the formulation based on polymers, the present study is important for a better comprehension of raw materials on topical formulations. Furthermore, this study can be useful for future pharmaceutical studies on topical formulations, giving information about better concentrations of polymers to be utilized. $(21,22,27)$

\section{Conclusions}

The Polyacrylamide (and) C13-14 Isoparaffin (and) Laureth-7 polymer was the modifying agent with the greatest influence on the physico-mechanical properties of the developed formulations when the concentration varied without changing the other raw materials of
Calixto e Maia Campos (2017) (12) mostraram em seu estudo que a relação entre firmeza e coesão era perfeita e positiva, ou seja, se um desses parâmetros aumenta, o outro também aumenta proporcionalmente. Em nosso estudo, isso acontece com todas as formulações à medida que a concentração de polímeros aumenta. No entanto, para o HEC a diferença entre os dois parâmetros foi muito superior em relação aos demais. Isso pode provavelmente afetar as propriedades sensoriais da formulação, uma vez que a coesão está relacionada ao desempenho da formulação quando aplicada, enquanto a firmeza está mais correlacionada com a estrutura da formulação. De fato, foi possível observar o comportamento muito semelhante entre o trabalho de cisalhamento e coesão nas medições (Figura 2). No entanto, para o polímero HEC, as alterações na concentração refletiram em um aumento maior na firmeza. Provavelmente porque o HEC não apresenta cadeias laterais em sua estrutura.

Viscosidades mais altas associadas aos carbômeros em comparação com outros polímeros sintéticos foram encontradas na literatura. $(23,24)$ Mesmo com este comportamento superior, todas as viscosidades em concentrações mínimas não apresentaram diferença significativa e valores baixos. Essa característica é desejada em veículos cosméticos por causa de seus altos valores de viscosidade, o que implica em um trabalho superior de cisalhamento na pele, prejudicando a espalhabilida) de. $(25,26)$

Todos os polímeros, com suas características estruturais, podem ajudar a melhorar as propriedades sensoriais; entretanto, o conhecimento sobre como os polímeros e suas concentrações podem influenciar as propriedades sensoriais é importante para a escolha correta dessas matérias-primas. (5)

Por fim, considerando que existem poucos estudos relatados que avaliam as propriedades físico- mecânicas de formulações à base de polímeros, o presente estudo contribui para uma melhor compreensão do comportamento das matérias-primas adicionadas em formulações de uso tópico. Além disso, pode contribuir para futuros estudos farmacêuticos que envolvem o desenvolvimento de formulações tópicas fornecendo informações sobre melhores concentrações de polímeros a serem utilizados. $(21,22,27)$

\section{Conclusões}

O polímero Poliacrilamida (e) C13-14 isoparafina (e) Laureth-7 foi o agente modificador com maior influencia nas propriedades físico-mecânicas das formulações desenvolvidas quando variou-se a concentração sem 
the formulations. On the other hand, the Ammonium Acryloyldimethyltaurate/VP Copolymer did not alter the physico-mechanical properties of the formulations studied. The HEC polymer showed to be more instable with increasing concentration. For the carboxyvinilic polymer, a significant alteration in the parameters was observed when the lowest and the highest concentrations of the polymer were applied in the developed formulations.

Finally, the type of polymers, as well as its lateral chains, could result in formulations with different physico-mechanical properties, reflecting its performance when applied on the skin. Therefore, the evaluation of the physico-mechanical properties of cosmetic formulations contributes to a better understanding of the behavior of the formulations during application on the skin, which can influence in the performance and acceptance of the same.

\section{Acknowledgments}

We would like to thank FAPESP - Fundação de Amparo à Pesquisa no Estado de São Paulo (proc 2014/11460-5) for the financial support received.

\section{Conflict of Interests}

None of the authors declared any conflict of interests alterar as demais matérias-primas das formulações. Por outro lado, o Acryloydimethyltaurate de Amônio / Copolímero VP, não alterou as propriedades físico-mecânicas das formulações estudadas. O polímero HEC mostrou-se mais instável com o aumento da concentração. O tipo de polímero, assim como suas cadeias laterais, poderia resultar em formulações com propriedades físico-mecânicas diferentes, refletindo sobre seu desempenho na superfície da pele. Portanto, a avaliação das propriedades físco-mecânicas de formulações cosméticas contribui para um melhor entendimento do comportamento das formulações durante a aplicação na pele, o que pode influenciar no desempenho e aceitação das mesmas.

\section{Agradecimentos}

Gostaríamos de agradecer à Fundação de Amparo à Pesquisa do Estado de São Paulo - FAPESP (proc 2014/11460-5) pelo apoio financeiro recebido.

\section{Conflito de Interesses}

Nenhum dos autores declarou qualquer conflito de interesses 


\section{References/ Referências}

1. Munoz, A. M., and G. V. Civille. "The spectrum descriptive analysis method." Manual on descriptive analysis testing for sensory evaluation (1992): $22-34$.

2. Stone, Herbert, et al. "Sensory evaluation by quantitative descriptive analysis." Descriptive Sensory Analysis in Practice (2008): 23-34.

3. Meullenet, J-FC, et al. "Bi-cyclical instrument for assessing texture profile parameters and its relationship to sensory evaluation of texture." Journal of Texture Studies 28.1 (1997): 101-118.

4. Gilbert, Laura, et al. "Impact of polymers on texture properties of cosmetic emulsions: a methodological approach." Journal of Sensory Studies 27.5 (2012): 392-402.

5. Wasan, D. T., A. D. Nikolov, and F. Aimetti. "Texture and stability of emulsions and suspensions: role of oscillatory structural forces." Advances in colloid and interface science108 (2004): 187-195.

6. Gilbert, Laura, et al. "Predicting sensory texture properties of cosmetic emulsions by physical measurements." Chemometrics and Intelligent Laboratory Systems 124 (2013a): 21-31.

7. Parente, Maria Emma, and G. Solana. "Study of sensory properties of emollients used in cosmetics and their correlation with physicochemical properties." International Journal of Cosmetic Science 27.6 (2005): 354-354.

8. Dooley, Lauren M., Koushik Adhikari, and E. D. G. A. R. CHAMBERS IV. "A general lexicon for sensory analysis of texture and appearance of lip products." Journal of sensory studies 24.4 (2009): 581-600.

9. Lee, In-Suk, et al. "Terminology development and panel training for sensory evaluation of products including aqua cream." Journal of sensory studies 20.5 (2005): 421-433.

10. Jones, D. S., and A. D. Woolfson. "Measuring sensory properties of semi-solid products using..." Pharmaceutical Manufacturing Review 9.1 (1997): S3-S3.

11. Armanet, Luc, and David Hunkeler. "Phase inversion of polyacrylamide-based inverse-emulsions: Influence of inverting-surfactant type and concentration." Journal of applied polymer science 103.6 (2007): 3567-3584

12. Calixto, Lívia Salomão, and P. M. B. G. Maia Campos. "Physical-Mechanical characterization of cosmetic formulations and correlation between instrumental measurements and sensorial properties." International journal of cosmetic science 39.5 (2017): 527-534.

13. Yılmaz, Emin, and Mustafa Öğ̈̈tcü. "Comparative analysis of olive oil organogels containing beeswax and sunflower wax with breakfast margarine." Journal of food science 79.9 (2014): E1732-E1738.

14. Calixto, Lívia Salomão, Victor Hugo Pacagnelli Infante, and Patrícia MBG Maia Campos. "Design and Characterization of Topical Formulations: Correlations Between Instrumental and Sensorial Measurements." AAPS PharmSciTech (2018): 1-8.

15. Cruz-Silva, Rodolfo, et al. "Enzymatic synthesis of pH-responsive polyaniline colloids by using chitosan as steric stabilizer." European polymer journal 43.8 (2007): 3471-3479.

16. Behera, B., et al. "Physical and mechanical properties of sunflower oil and synthetic polymers based bigels for the delivery of nitroimidazole antibiotic-A therapeutic approach for controlled drug delivery." European Polymer Journal 64 (2015): 253-264.

17, Lefrançois, Pauline, et al. "Insights into Carbopol gel formulations: Microscopy analysis of the microstructure and the influence of polyol additives." Journal of Applied Polymer Science 132.46 (2015).

18. Lin, Fang, et al. "Synthesis and structural characterization of methacrylic acid/octadecyl acrylate-graft-poly (methylhydrosiloxane) by hydrosilylation." Journal of applied polymer science 107.6 (2008): 3773-3780.

19. Wang, Wei, and Sv Arne Sande. "Monitoring of macromolecular dynamics during a chemical cross-linking process of hydroxyethylcellulose derivatives by dynamic light scattering." European Polymer Journal 58 (2014): 52-59.

20. Donnelly, Marc W., Mahilet Hailemichael, and Matthew W. Liberatore. "Altering the viscosity of cationically modified cellulose polymers by the addition of salt." Journal of Applied Polymer Science 132.11 (2015).

21. Gilbert, Laura, et al. "Rheological and textural characterization of cosmetic emulsions containing natural and synthetic polymers: relationships between both data." Colloids and Surfaces A: Physicochemical and Engineering Aspects 421 (2013b): 150-163.

22. Jones, David S., A. David Woolfson, and Andrew F. Brown. "Textural, viscoelastic and mucoadhesive properties of pharmaceutical gels composed of cellulose polymers." International journal of pharmaceutics 151.2 (1997): 223-233.

23. Graessley, William W. "Polymer chain dimensions and the dependence of viscoelastic properties on concentration, molecular weight and solvent power." Polymer 21.3 (1980): 258-262.

24. Limsuwan, Tunyaluk, Prapaporn Boonme, and Thanaporn Amnuaikit. "Study on the Antioxidant Activities of Gel Containing Tagetes erecta (L.)." Advanced Materials Research. Vol. 747. Trans Tech Publications, 2013.

25. Montenegro, Lucia, et al. "Effects of lipids and emulsifiers on the physicochemical and sensory properties of cosmetic emulsions containing vitamin E." Cosmetics 2.1 (2015): 35-47.

26. Schwartz, Naomi Oshinsky. "Adaptation of the sensory texture profile method to skin care products." Journal of Texture Studies 6.1 (1975): $33-42$.

27. Mendes Fossa Shirata, Marina, and Patrícia Maria Berardo Gonçalves Maia Campos. "Importância do perfil de textura e sensorial no desenvolvimento de formulações cosméticas." Surgical \& Cosmetic Dermatology 8.3 (2016). 